\title{
Study on the effect of packaging on the freshness of spinach
}

SHWETA PRIYADARSHINI AND MUKTA SINGH

Received: 19.01.2015; Revised: 05.04.2015; Accepted: 20.04.2015

See end of the paper for authors' affiliations SHWETA PRIYADARSHINI Department of Home Science, Mahila Mahavidhyalaya, Women College (B.H.U.) VARANASI (U.P.) INDIA
ABSTRACT : The post harvest industry is expected to supply good quality fruit and vegetables to consumers throughout the year from various and distant fields. Post harvest products are living and respiring materials and from field to fork, several factors influence quality. In this study, focus was mainly on leafy green vegetables and so spinach was taken as the subject. The primary aim of this study was to determine the effect of perforated packaging and temperature on the retention of ascorbic acid and iron in spinach. Organically grown, fresh spinach leaves were taken from kitchen garden and were separated into three equal parts. Two portions (Sample 1 and 2) were packed in 40 micron thick plastic film and after heat sealing the packets were perforated with a medical needle. Sample 1 and sample 3 (unpacked), were stored at $4^{\circ} \mathrm{C}$ and sample 2 was stored at $-18^{\circ} \mathrm{C}$. After 6 days of storage fresh spinach (sample 4) was taken from same kitchen garden. All the samples were then evaluated for iron and ascorbic acid. The iron content in sample was determined by UV- Spectrophotometry method and the ascorbic acid content was determined by 2, 6 dichloroindophenol titrimetric method (AOAC). Furthermore, weight loss was evaluated and sensory analysis was used for describing the quality changes such as physical appearance, texture/shrinkage and to ascertain the overall acceptability. The result of sensory analysis was then subjected to ANOVA, for statistical analysis. In this study greater retention of ascorbic acid $(84.6 \%)$ was observed during storage of sample (sample 1) in perforated plastic film at $4^{\circ} \mathrm{C}$ as compare to sample 2 , stored at $-18^{\circ} \mathrm{C}(69.3 \%)$ and sample 3 , stored unpacked $(58.7 \%)$. The greater retention of iron was also observed in the same sample $(85.8 \%)$. It also had the higher overall acceptability as compared to other two samples. Further, it got highest score of 6.8 for overall acceptability on $6^{\text {th }}$ day of storage. Thus, in the present study the quality retention was superior with perforated packaging at $4^{\circ} \mathrm{C}$ storage temperature.

KEY WORDS: Spinach, Perforated packaging, Retention of iron, Retention of ascorbic acid, Temperature

- HOW TO CITE THIS PAPER : Priyadarshini, Shweta and Singh, Mukta (2015). Study on the effect of packaging on the freshness of spinach. Asian J. Home Sci., 10 (1) : 123-128. 